\title{
PREVALENCE OF MICROSCOPIC COLITIS IN PATIENTS FULFILLING ROME IV CRITERIA OF IRRITABLE BOWEL SYNDROME DIARRHEAL TYPE
}

\author{
By
Mohammed A. Abd El-Fattah Badran, Mohamed S. Rozik, Olfat A. Hammam* and Mohamed G. Mohamed \\ Department of Hepatogasteroenterology and Infectious Diseases, Faculty of Medicine, Al- \\ Azhar University, Cairo, Egypt \\ *Department of Histopathology, Theodor Bilharz Research Institute. \\ Corresponding author: Mohammed A. Abd El Fattah, \\ E-mail: mohamadbadran2010@gmail.com
}

\begin{abstract}
Background: Diarrhea predominant irritable bowel syndrome (IBS-D) is a common functional disorder of the gastrointestinal tract shares similar symptoms and endoscopic findings with microscopic colitis (MC) with a major difference in treatment. IBS-D is diagnosed using criteria based on clinical symptoms, while histological evidence is mandatory for MC diagnosis. There is a continuous debate about the value of endoscopically normal colonic mucosa biopsies in IBS-D patient investigation.
\end{abstract}

Objective: To determine the prevalence of MC in patients meeting Rome IV criteria of IBS-D.

Patients and methods: A cross-sectional survey was performed in the Department of Hepatogastroenterology and Infectious Diseases, Al-Azhar University Hospitals. One hundred patients attended the outpatient clinics from January 2020 to April 2020 fulfilling Rome IV criteria for diagnosis of IBS-D was prospectively enrolled. Patients aged from 18 to 65 years old. Patients with other causes of chronic diarrhea were excluded. The studied patients were subjected to full history taking, extensive clinical examination, thorough laboratory investigations and complete colonoscopy with multiple biopsies were taken from endoscopically normal looking mucosa at different parts of the colon, and processed for histopathological examination.

Results: The mean age of participants was $40.7 \pm 11.01$ years. Fifty three cases were males (53\%) and 47 were females (47\%). Twenty out of 100 patients were diagnosed as MC, $18(90 \%)$ of them were lymphocytic colitis (LC) and 2 patients (10\%) were collagenous colitis (CC). The mean age in MC patients was $50.8 \pm 7.3$ years. Nocturnal diarrhea and weight loss were only seen in cases diagnosed as MC (15 out of 20 patients $75 \%$ ) and 15 out of 20 patients (75\%) respectively. There was a significant difference between normal biopsy \& MC patients as regard inflammatory markers C-reactive protein(CRP) and Erythrocyte sedimentation rate (ESR), but their levels were still within normal range.

Conclusion: MC is not an uncommon disease that is often diagnosed in elderly people. It can be easily confused with IBS-D and histopathological examination of colonoscpic biopsies obtained from the normally appearing mucosa is the only way for differentiation. In cases with IBS-D, nocturnal diarrhea and weight loss increase the possibility of MC and require colonoscopic biopsy evaluation. In patients with IBS-D criteria mild increase in inflammatory markers (CRP and ESR) may occur, but these markers are non-specific and don't direct us for MC diagnosis.

Keywords: Microscopic colitis, Irritable bowel syndrome, Colonoscopy. 


\section{INTRODUCTION}

Microscopic colitis (MC) is a chronic inflammatory disorder of the large intestine that mainly affects the elderly. MC differs from "classical" inflammatory bowel disease (IBD) in its almost normalappearing colonic mucosa and histological findings consistent with increased lymphocytic infiltrates with or without collagen fiber expansion (Khalili et al., 2020). MC has two major subtypes, lymphocytic colitis (LC) and collagenous colitis (CC) (Shor et al., 2019).

The incidence of $\mathrm{MC}$ is rising globally and seen mainly in people over 60 years of age and more often in women. The incidence is $4.9 / 100$ per person year in LC and 4.1 in CC (Tulassay et al., 2020).

Autoimmune conditions such as rheumatoid arthritis and thyroiditis. Have been often described in MC, but there is no clear immunological evidence supporting these associations (Miehlke et al., 2019).

Patients of MC presented with watery diarrhea. This can start off suddenly or insidiously. Stool frequency usually varies from 4-9 motions per day, but can exceed 10 motions per day (Townsend et al., 2019).

Histological examination is mandatory for MC diagnosis. In LC, there are chronic inflammatory infiltration with excessive lymphocyte and plasma cells in the lamina propria, and lymphocytic count of more than 20/100 epithelial cells are seen. In $\mathrm{CC}$, subepithelial collagen is thickened more than $10 \mu \mathrm{m}$ (Tulassay et al., 2020).

Many possible biomarkers for MC have been investigated, but none are diagnostic. Similarly, macroscopic findings have been identified in $\mathrm{MC}$ patients, and are present in approximately one-third of patients, but are not unique to the disease. Thus, histological examination of colonic biopsies is still the only method of diagnosing MC. Importantly, a major barrier to colonic biopsy evaluation in patients with $\mathrm{MC}$ is its clinical overlap with IBS (Münch et al., 2020).

IBS is a widespread functional bowel disease affecting 11.2 percent of the global population. As a chronic disorder, IBS is characterized by abdominal pain or bloating associated with changes in large intestinal habits, and is further subdivided into four patterns: diarrhea-predominant (IBS-D), constipation-predominant (IBSC), mixed subtype (IBS-M), and unsubtyped (IBS-U). Due to the absence of biomarkers and organic lesions, gastroenterologists depend on clinical manifestations to diagnose IBS, based on the Rome criteria (Duan et al., 2019).

The Rome IV criteria for diagnosis of IBS require that patients have had recurrent abdominal pain on average at least one day weekly over the preceding three months, which is associated with two or more of the following: Related to defecation, change in the frequency of the stool, and change in the form or appearance of the stool (Brian et al., 2016).

Patients with IBS-D, or functional diarrhea share common symptoms and endoscopic findings with MC patients, all of which have a significant negative effect on health-related quality of life (Guagnozzi et al., 2016).

MC is more difficult to differentiate from IBS-D because patients present with 
chronic watery diarrhea and often have no weight loss. These forms of colitis also have an entirely normal endoscopic appearance (Macaigne et al., 2014). If colonoscopy is done in patients suspected of having IBS-D, random colon biopsies should be done to rule out MC (Münch et al., 2020).

There is a difference between treatment of IBS predominant diarrhea which include antidiarrheal drugs and antibiotics as rifaximin, and treatment of MC which require antidiarrheal drugs and corticosteroids even may need use of immunomodulators such azathioprine, methotrexate as in severe cases, and may reach surgical intervention (Pardi, 2017). In both American Gastroenterological Association guidelines and European Microscopic Colitis Group Statements Budesonide is recommended as first-line treatment for MC (Townsend et al., 2019).

The aim of this study was to assess the prevalence of $\mathrm{MC}$ in patients meeting the Rome IV criteria for IBS-D patients.

\section{PATIENTS AND METHODS}

A cross-sectional study was conducted in the Department of Hepatogastroenterology and Infectious Diseases, Al-Azhar University Hospitals. One hundred patients attended the outpatient clinics from January 2020 to April 2020 fulfilling Rome IV criteria for diagnosis of IBS-D was prospectively enrolled in the study.

The participants have been informed about the study and its aim and informed consents were declared from all participants.

\section{Inclusion criteria:}

- All patients with IBS-D who fulfilled the diagnostic criteria of Rome IV and had normal colonoscopy findings.

- Patients aged from 18 to 65 years old.

Exclusion criteria:

- Infectious colitis

- Inflammatory bowel diseases (ulcerative colitis, crohns disease and indeterminate colitis).

- Systemic disease associated with chronic diarrhea, e.g. Diabetes mellitus and Thyroid disease.

- Drugs causing chronic diarrhea, e.g. antibiotics, antidepressants and angiotensin converting enzyme inhibitors.

- Chronic diarrhea due to decreased digestion as in pancreatic insufficiency and bile acid deficiency.

The studied patients underwent the following:

1. Full history taking and thorough clinical examination.

2. Laboratory investigations, including: $\mathrm{CBC}$, renal function tests and electrolytes, included blood urea, serum creatinine, serum sodium $(\mathrm{Na})$ and potassium $(\mathrm{K})$, liver function tests included serum transaminases (AST, ALT), serum albumin, serum bilirubin (total, direct), prothrombin time and concentration, inflammatory markers (CRP, ESR), TSH, FBS and 2 hr.PPBS, Stool analysis and culture. 
3. Colonoscopy and biopsy sampling procedure:

All included patients underwent full colonoscopy under conscious sedation after Bowel preparation for 2 days prior to the procedure and after written informed consent.

Multiple biopsies were obtained from the normal appearing mucosa at different parts of the colon with at least two biopsies from each site: the right sided colon (cecum, ascending colon, and transverse colon), left sided colon (descending colon and sigmoid colon) and the rectum .Biopsies were at once placed in bottles with $10 \%$ formalin and sent for processing in the pathology lab under supervision of gastrointestinal pathologist. The tissues were prepared for light microscopic examination and evaluated by a pathologist using Hematoxylin -Eosin staining. In those doubtful cases, a Masson trichrome staining was performed, to optimally determine the presence of a collagen layer.

The number of IEL was calculated by counting the lymphocytes per 100 intercryptal epithelial cells. At least, five non-contiguous intercryptal spaces, except lymphoid follicles zones were examined and the mean number of IEL was expressed per 100 epithelial cells. The thickness of the subepithelial collagen band was measured using an optical micrometer. The biopsies were considered as normal when there were less than five IEL /100 surface epithelial cells, the collagen layer was less than $5 \mu \mathrm{m}$ and no other pathological changes in the epithelium and lamina propria were found. The biopsies considered abnormal when there was $\geq 20$ IEL per 100 surface epithelial cells, thickening of a subepithelial collagen layer of more than $10 \mathrm{um}$, and pathological changes of the lamina propria (Münch et al., 2012).

\section{Statistical analysis:}

Data was revised and analyzed using version 24 of the SPSS software package. Quantitative data were expressed as mean \pm standard deviation (SD). Qualitative data were expressed in terms of frequency and percentage. Statistical analysis was done using the MannWhitney U test Fisher's extract was used to compar qualitative data and, the Chisquare test to compare qualitative data.

P-value of less than 0.05 was considered statistically significant. 


\section{RESULTS}

This study had been carried out on 100 patients attended gastroenterology outpatient clinics of Al-Azhar University Hospitals. The included patients fulfilled The Rome IV criteria for diagnosis of IBS and their age ranged between 20 and 60 years, with a mean age of $40.7 \pm 11.01$ years. 53 cases were males $(53 \%)$ and 47 were females $(47 \%)$. The microscopic examination of the colonic biopsies that were taken after endoscopic examination of the studied patients revealed that 20 patients were diagnosed as MC, $18(90 \%)$ of them were LC, and 2 patients (10\%) were $\mathrm{CC}$.The major clinical manifestations in the studied patients were Abdominal distention (55\%), Nocturnal diarrhea $(15 \%)$ and weight loss $(15 \%)$ (Table 1).

Table (1): Age, sex, microscopic colitis and clinical manifestations distribution of all studied patients

\begin{tabular}{|c|c|c|c|}
\hline \multirow{2}{*}{ Age (years) } & \multicolumn{2}{|c|}{ Studied patients (N = 100) } \\
\cline { 2 - 4 } & Mean \pm SD & \multicolumn{2}{|c|}{$40.7 \pm 11.01$} \\
\hline \multirow{2}{*}{ Sex } & Min - Max & \multicolumn{2}{|c|}{$20-60$} \\
\cline { 2 - 4 } & Male & 53 & $53 \%$ \\
\hline \multirow{2}{*}{$\begin{array}{c}\text { Microscopic colitis } \\
(\mathbf{N}=\mathbf{2 0})\end{array}$} & Female & 47 & $47 \%$ \\
\cline { 2 - 4 } & Collagenous & 18 & $90 \%$ \\
\hline \multirow{2}{*}{ Abdominal Distention } & Yes & $\mathbf{5 5}$ & $\mathbf{5 5 \%}$ \\
\cline { 2 - 4 } & $\mathbf{N o}$ & 45 & $45 \%$ \\
\hline \multirow{2}{*}{ Nocturnal diarrhea } & Yes & $\mathbf{1 5}$ & $\mathbf{1 5 \%}$ \\
\cline { 2 - 4 } & $\mathbf{N o}$ & 85 & $85 \%$ \\
\hline \multirow{2}{*}{ Weight loss } & Yes & $\mathbf{1 5}$ & $\mathbf{1 5 \%}$ \\
\cline { 2 - 4 } & $\mathbf{N o}$ & & $85 \%$ \\
\hline
\end{tabular}

The mean age in normal biopsy was $38.2 \pm 10.3$ years while it was $50.8 \pm 7.3$ years in microscopic colitis patients with highly significant difference (P-value < $0.001)$.There were 50 males $(62.5 \%)$ and
30 females (37.5) in normal biopsy patients while there were 3 males $(15 \%)$ and 17 females (85) in microscopic colitis patients with highly significant difference (P-value < 0.001).

Table (2): Age and sex distribution in relation to biopsy result

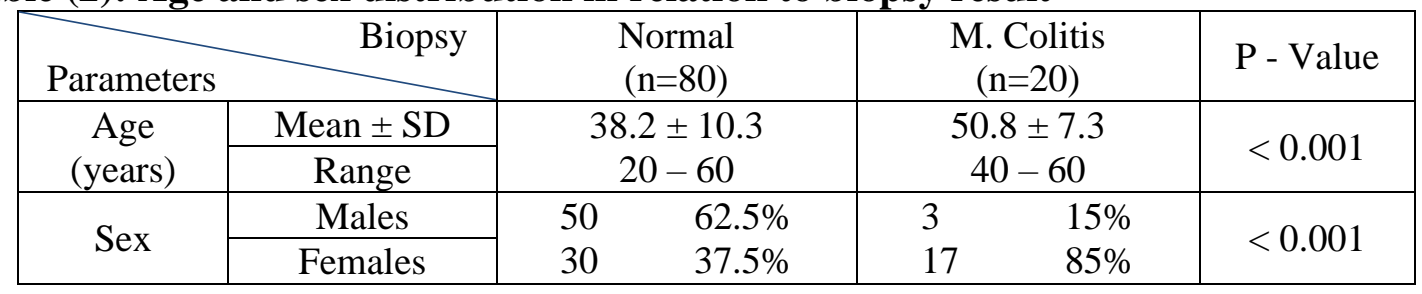

The mean duration of symptoms prior to histological diagnosis and the mean stool frequency per day in MC patients was $8.7 \pm 2.5$ months and $5.7 \pm 2.5$ motion per day comparing to $8.1 \pm 4.4$ months and $6.6 \pm 2.3$ motion per day for those with normal biopsy results with insignificant difference $(\mathrm{P}$-value $=0.051$ and 0.130 respectively) . 
There was a statistically significant difference (p-value $<0.001)$ between normal biopsy and MC patients as regard inflammatory markers CRP \& ESR. As regard CRP, the mean CRP in normal biopsy was $3.2 \pm 1.02 \mathrm{mg} / \mathrm{L}$, while it was
$8.2 \pm 1.7 \mathrm{mg} / \mathrm{L}$ in MC patients. As regard ESR, the mean of ESR in normal biopsy was $6.3 \pm 3.3 \mathrm{~mm} /$ hour while it was 16.9 $\pm 4.9 \mathrm{~mm} /$ hour in microscopic colitis patients (Table 3).

Table (3): Comparison of duration of symptoms, motions per day and inflammatory markers (CRP and ESR) as regard biopsy results

\begin{tabular}{|c|c|c|c|c|}
\hline \multicolumn{2}{|c|}{$\begin{array}{ll}\text { Parameters } & \text { Biopsy } \\
\end{array}$} & $\begin{array}{l}\text { Normal } \\
(\mathrm{n}=80)\end{array}$ & $\begin{array}{l}\text { M. Colitis } \\
(\mathrm{n}=20)\end{array}$ & P-value \\
\hline \multirow{2}{*}{$\begin{array}{l}\text { Duration } \\
\text { (months) }\end{array}$} & Mean \pm SD & $8.1 \pm 4.4$ & $8.7 \pm 2.5$ & \multirow{2}{*}{0.051} \\
\hline & Range & $5-25$ & $5-13$ & \\
\hline \multirow{2}{*}{$\begin{array}{c}\text { Motions } \\
\text { (motion / day) }\end{array}$} & Mean \pm SD & $6.6 \pm 2.3$ & $5.7 \pm 2.5$ & \multirow{2}{*}{0.130} \\
\hline & Range & $3-10$ & $2-10$ & \\
\hline \multirow{2}{*}{$\mathrm{CRP}(\mathrm{mg} / \mathrm{L})$} & Mean \pm SD & $3.2 \pm 1.02$ & $8.2 \pm 1.7$ & \multirow{2}{*}{$<0.001$} \\
\hline & Range & $2-7$ & $6.4-12.3$ & \\
\hline \multirow{2}{*}{$\operatorname{ESR}(\mathrm{mm} / \mathrm{h})$} & Mean \pm SD & $6.3 \pm 3.3$ & $16.9 \pm 4.9$ & \multirow{2}{*}{$<0.001$} \\
\hline & Range & $3-15$ & $10-26$ & \\
\hline
\end{tabular}

Nocturnal diarrhea and weight loss were observed only in cases diagnosed as MC (15 patients out of $20(75 \%)$ and 15 patients out of $20(75 \%)$ respectively) with highly statistical significant difference ( $\mathrm{p}$-value $<0.001$ ) between normal biopsy and MC patients (Table 4).

Table (4): Distribution of clinical manifestations in relation to biopsy results

\begin{tabular}{|c|c|c|c|c|c|c|}
\hline \multicolumn{2}{|c|}{ Parameters Biopsy } & \multicolumn{2}{|c|}{$\begin{array}{l}\text { Normal } \\
(\mathrm{n}=80)\end{array}$} & \multicolumn{2}{|c|}{$\begin{array}{l}\text { M. Colitis } \\
(\mathrm{n}=20)\end{array}$} & P-value \\
\hline \multirow{2}{*}{$\begin{array}{c}\text { Nocturnal } \\
\text { diarrhea }\end{array}$} & Yes & 0 & $0 \%$ & 15 & $75 \%$ & \multirow{2}{*}{$<0.001$} \\
\hline & $\mathrm{NO}$ & 80 & $100 \%$ & 5 & $25 \%$ & \\
\hline \multirow{2}{*}{ Weight loss } & Yes & 0 & $0 \%$ & 15 & $75 \%$ & \multirow{2}{*}{$<0.001$} \\
\hline & $\mathrm{NO}$ & 80 & $100 \%$ & 5 & $25 \%$ & \\
\hline \multirow{2}{*}{ Distension } & Yes & 45 & $56.25 \%$ & 10 & $50 \%$ & \multirow{2}{*}{0.615} \\
\hline & $\mathrm{NO}$ & 35 & $43.75 \%$ & 10 & $50 \%$ & \\
\hline
\end{tabular}

\section{DISCUSSION}

The colonoscopy results in all studied patients showed normal colonic mucosa and normal vasculature with no ulcers, masses or diverticula, while the microscopic examination of biopsies from multiple sites of the endoscopically normal colonic mucosa revealed that (20\%) had histologic picture consistent with MC with $90 \%$ of them were lymphocytic colitis and $10 \%$ of them were collagenous colitis. This result agreed with that reported by Carmona-Sánchez et al. (2011) who found that the prevalence of MC in IBS-D patients was $18 \%$. Also, agreed with the results of Kamp et al. (2016) who studied the prevalence of MC in patients with symptoms suggesting IBS and reported a prevalence of $23.3 \%$.

Our results were not coinciding with that revealed by Chey et al. (2010) that reported $\mathrm{MC}$ in only $1.5 \%$ of patients with 
IBS as they did not obtain colonic biopsy samples in the control group for practical and cost related reasons. The result of MC prevalence in this study also was not compatible with the study of Ozdil et al. (2011) that reported MC in $3.1 \%$ of IBS patients, as his analysis was not restricted to IBS-D subtype, but to all IBS cases.

There are two retrospective studies conducted in Egypt by Gado et al. (2011) on chronic watery diarrhea and normal colonoscopy findings and by Saleh et al. (2016) on patients with chronic nonbloody diarrhea and normal colonoscopy findings. They found that (50\%) and $(29.5 \%)$ of patients, respectively had MC. The two studies showed higher prevalence of MC than in our study, because not all the studied subjects were fulfilling Rome criteria, and both were conducted on chronic diarrhoea rather than IBS-D.

Another Bangladeshi study done by Rahman et al. (2012) showed that out of sixty patients, who were primarily diagnosed as IBS-D, (36.7\%) patients fulfilled the histological criteria of $\mathrm{MC}$ based on histological examination, which is not compatible with our study, may be due to smaller sample size i.e. 60 patients vs 100 patients in our study and different age distribution, i.e. the mean age was $(31.07+8.16$ years $)$ compared to $(40.7 \pm$ 11.01 years) in our study.

The percentage of the MC subtypes in the present study was 9 (LC) to 1 (CC). This was in accordance with Guagnozzi et al. (2016) who showed that the prevalence of LC among patients with a primary diagnosis of IBS was greater than that of CC. Also, it was consistent with a Turkish study conducted by Erdem et al. (2011) on 129 patient with non-bloody diarrhea and revealed that $\mathrm{LC}$ is prevalent than $\mathrm{CC}$ (LC in (9\%) and CC only in (2.5\%).

Taken together, the results of the mentioned studies, though different in their conclusion, regarding the prevalence of MC, have made it clear that MC is not an uncommon disease, and as it can be easily confused with IBS-D and both conditions have a normal-appearing mucosa during colonoscopy findings, The only way for diagnosing MC is through multiple biopsies taken from the normally appearing mucosa

Our study showed that the mean age of patients diagnosed as MC was $50.8 \pm 7.3$ years. This agreed with that reported by Pardi (2017) who revealed that MC was more common in older persons. This finding also was compatible with another study conducted by Miehlke et al. (2020) and showed that $\mathrm{MC}$ is more common in old age. On the other hand, this finding was not compatible with the study on by Rahman et al. (2012) in which the main age of patients was (31.13 \pm 7.54$)$ years and this may be due to smaller sized sample of patients compared to our study.

As regard sex distribution in the present study, male patients were $53 \%$, while females were $47 \%$. There was a female predominance in MC patients with a ratio of 5:1.this result was constant with Verhaegh et al. (2015) who reported that female: male ratio is 3:1. Pardi (2017) revealed that female to male ratio is $9: 1$ while other authors reported that both sexes were affected equally Saleh et al (2017) who showed that MC patients have the same ratio between males and females, but the latter study was conducted on all types of IBS, not only IBS-D like our study. 
The major clinical manifestations in the studied patients were abdominal distention $(55 \%)$, nocturnal diarrhea $(15 \%)$ and weight loss (15\%) with significant difference between patients with MC and those with normal biopsy in relation to nocturnal diarrhea, and weight loss as 15 patients (75\%) with MC had nocturnal diarrhea and $75 \%$ had weight loss. This result agreed with the study conducted by Stoicescu et al. (2012) who showed that $73.3 \%$ of his patients with MC have nocturnal diarrhea, and $40 \%$ of the same group has weight loss.

The mean stool frequency per day in this study ranged from 2 to 10 motions per day which agreed with the study of Stoicescu et al. (2012) showed mean stool frequency from 3 to 12 . In our study, the duration of symptoms prior to histological diagnosis of MC ranged from 5 to 13 months with a mean of $8.7 \pm 2.5$ months, which was consistent with Melo Uribe et al. (2013) which showed that the duration of symptoms before diagnosis were between 3 to 30 months with average duration 24 months.

Our study revealed statistically significant difference between normal biopsy and MC patients as regard CRP \& ESR. As regard CRP, the mean CRP in normal biopsy was $3.2 \pm 1.02 \mathrm{mg} / \mathrm{L}$, while it was $8.2 \pm 1.7 \mathrm{mg} / \mathrm{L}$ in MC patients. As regard ESR, the present study showed elevation of ESR level in MC patients which ranged from $(10-26 \mathrm{~mm} / 1 \mathrm{st} \mathrm{hr}$ ), while in normal biopsy ranged from (3- 15 $\mathrm{mm} / 1 \mathrm{st} \mathrm{hr}$ ). This result agreed with the study of Boland and Nguyen (2017) who reported that about $50 \%$ of $\mathrm{MC}$ patients have mild elevation of inflammatory markers and mild anemia. Also, this finding is supported by Bohr et al. (2014) who said that only nonspecific abnormalities may be found in patients with MC such as moderate increase in levels of CRP and ESR or mild anemia and these tests are non-diagnostic. Despite this significant variation in inflammatory markers between the normal biopsy patients and MC patients, these markers are still within the normal range, So we, cannot rely on them as surrogate markers for suspecting MC in IBS-D patients since they are non-specific and will not direct us to diagnose MC. This conclusion is in accordance with Cotter et al. (2017) who do not recommend the use of inflammatory markers for MC diagnosis as they are not sensitive or specific.

\section{CONCLUSION}

$\mathrm{MC}$ is not an uncommon disease that is often diagnosed in elderly people. It can be easily confused with IBS-D and histopathological examination of colonoscpic biopsies obtained from the normally appearing mucosa is the only way for differentiation. In patients with IBS-D, nocturnal diarrhea and weight loss increase the possibility of $\mathrm{MC}$ and require colonoscopic biopsy evaluation. In patients with IBS-D criteria mild increase in inflammatory markers (CRP and ESR) may occur, but these markers are nonspecific and don't direct us for MC diagnosis.

\section{REFERENCES}

1. Bohr J, Wickbom A, Hegedus A, Nyhlin N, Hörnquist E and Tysk C (2014): Diagnosis and management of microscopic colitis: current perspectives. Clinical and Experimental Gastroenterology, 7: 273-76.

2. Boland K and Nguyen C (2017): Microscopic colitis: a review of collagenous and 
lymphocytic colitis. Gastroenterology \& Hepatology, 13: 671-76.

3. Brian E, Mearin F, Chang L, Chey W, Lembo A, Simren $M$ and Spiller R (2016): Bowel disorders. Gastroenterology, 150: 13931407.

4. Carmona-Sanchez R, Carrera-Alvarez MA and Perez-Aguilar RM (2011): Prevalence of microscopic colitis in patients with irritable bowel syndrome with diarrhea predominance. Revista de gastroenterologia de Mexico, 76: 39-44.

5. Chey WD, Nojkov B, Rubenstein JH, Dobhan RR, Greenson JK and Cash BD (2010): The yield of colonoscopy in patients with non-constipated irritable bowel syndrome: results from a prospective, controlled US trial. Am J Gastroenterol., 105:859-865.

6. Cotter TG, Kamboj AK, Hicks SB, Tremaine WJ, Edward VL and Pardi DS (2017): The definition of budesonide dependence in microscopic colitis-authors' reply. Alimentary Pharmacology \& Therapeutics, 46: 636-636.

7. Gado AS, Ebeid BA, El Hindawi AAz, Akl MM and Anthony T (2011): Axon prevalence of microscopic colitis in patients with chronic diarrhea in Egypt: a single-center study. Saudi J Gastroenterol., 17:383-386.

8. Guagnozzi D, Arias Á and Lucendo AJ (2016): "Systematic review with meta-analysis: diagnostic overlap of microscopic colitis and functional bowel disorders. Alimentary Pharmacology \& Therapeutics, 43: 851-862.

9. Kamp EJ, John SK and Alexander CF (2016): Irritable bowel syndrome and microscopic colitis: a systematic review and meta-analysis. Clinical Gastroenterology and Hepatology, 14: 659-668.

10. Khalili H, Kristin EB, Bjorn R, Michael CS, Olén $O$ and Ludvigsson $J$ (2020): Microscopic colitis and risk of inflammatory bowel disease in a nationwide cohort study. Gastroenterology, 158(6):1574-1583.

11. Macaigne, G., Lahmek, P., Locher, C., Lesgourgues, B., Costes, L., Nicolas, M.P., Courillon-Mallet, A., Ghilain, J.M., Bellaïche, G., de Montigny-Lehnardt, S. and
Barjonet, G. (2014): Microscopic colitis or functional bowel disease with diarrhea: a French prospective multicenter study. American Journal of Gastroenterology, 109(9): 1461-1470.

12. Melo U, Alexander $M$ and Puentes $C$ (2013): A practical approach to histopathologic diagnosis of microscopic colitis. Revista Colombiana de Gastroenterologia, 28: 311-319.

13. Miehlke S, Bas V, Gian E, Ahmed M, Cord L and Münch A (2019): Microscopic colitis: pathophysiology and clinical management. The Lancet Gastroenterology \& Hepatology, 4: 305-314.

14. Miehlke S, Guagnozzi D, Zabana Y, Tontini GE, Fiehn AM, Wildt S, Bohr J, Bonderup O, Bouma G, D'Amato M, Engel PJ (2020): European guidelines on microscopic colitis: United European Gastroenterology (UEG) and European Microscopic Colitis Group (EMCG) statements and recommendations. United European Gastroenterology Journal. Aug 20:2050640620951905.

15. Münch A, Aust D, Bohr J, Bonderup O, Fernández Bañares $F$, Hjortswang $H$, Madisch A, Munck LK, Ström M and Tysk C (2012): Microscopic colitis: Current status, present and future challenges: statements of the European Microscopic Colitis Group. J Crohns Colitis, 6:932-945.

16. Münch A, Sanders SD, Molloy-Bland $M$ and Hungin AP (2020): Undiagnosed microscopic colitis: a hidden cause of chronic diarrhoea and a frequently missed treatment opportunity. Frontline Gastroenterol., 11(3): 228-234.

17. Ozdil, K., Sahin, A., Calhan, T., Kahraman, R., Nigdelioglu, A., Akyuz, U. and Sokmen, H.M (2011): The frequency of microscopic and focal active colitis in patients with irritable bowel syndrome. BMC gastroenterology, 11(1):96

18. Pardi DS (2017): Diagnosis and management of microscopic colitis." American Journal of Gastroenterology, 112: 78-85.

19. Rahman MA, Raihan AS, Ahamed DS, Masud H, Safiullah AB, Khair KB, Salimullah AS and Islam MM (2012): Symptomatic overlap in patients with diarrhea 
predominant irritable bowel syndrome and microscopic colitis in a sub group of Bangladeshi population. Bangladesh Medical Research Council Bulletin, 38: 33-38.

20. Duan R, Zhu S, Wang B, Duan L (2019): Alterations of gut microbiota in patients with irritable bowel syndrome based on 16S rRNAtargeted sequencing: a systematic review. Clinical and translational gastroenterology. Feb; 10(2).

\section{Saleh OM, Osman AM, Al-Attar MM, Rifai}

AM (2016): Prevalence of microscopic colitis in Upper Egypt among patients with chronic diarrhea and patients with irritable bowel syndrome. Journal of Current Medical Research and Practice. Sep 1;1(3):67.

22. Shor J, Gustavo C, Nooshin $H$ and Christopher M (2019): Management of microscopic colitis: challenges and solutions. Clinical and Experimental Gastroenterology, 12: 111-15.
23. Stoicescu A, Becheanu G, Dumbrava M, Gheorghe $C$ and Diculescu $M$ (2012): Microscopic colitis-a missed diagnosis in diarrhea-predominant irritable bowel syndrome. Maedica, 7: 3-6.

\section{Townsend T, Fiona $\mathbf{C}$, Paul $O$ and Chris $\mathbf{P}$} (2019): Microscopic colitis: diagnosis and management. Frontline Gastroenterology, 10: 388-393.

25. Tulassay Z, Emese $M$ and Lászlo $H$ (2020): Microscopic Colitis: A Challenging Disorder. Digestive Diseases, 38: 117-121.

26. Verhaegh BP, Jonkers DM and Driessen A (2015): Incidence of microscopic colitis in the Netherlands. A nationwide population-based study from 2000 to 2012. Dig Liver Dis., 47: $30-6$. 
معدل انتشار التهاب القولون الميكروسكوبى فى مرضى القيى

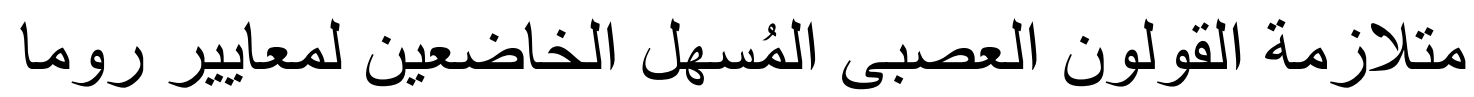
(4)

محمد عبدالسلام عبدالفتاح باران, محمد سعيد رزيق, ألفت على همام*, محمد غريب محمد

قسمى أمراض الكبد والجهاز الهضمي, والأمراض المعدية والباثولوجيا كلية الطب جامعة الازهر, و*معهد تيودور بلهارس للأبحاث

E-mail: mohamadbadran2010@gmail.com

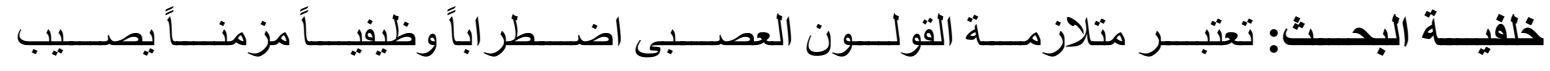

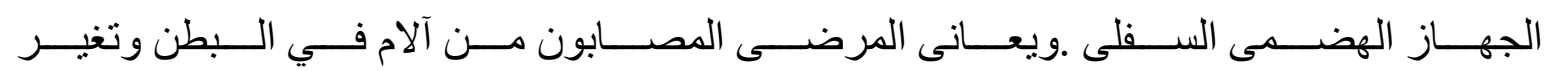

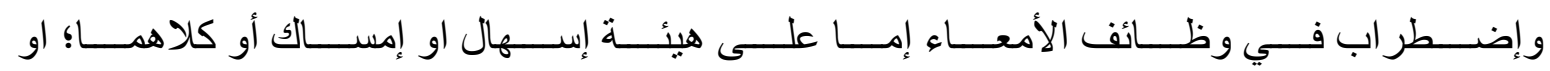

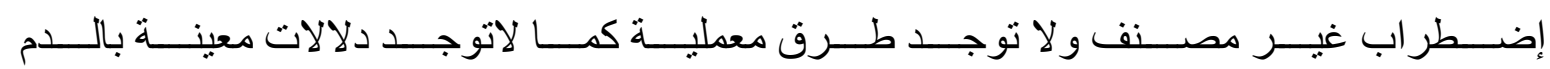
تعطى تشخيصا نهائيا محددا لمتلازمة القولون العصبى.

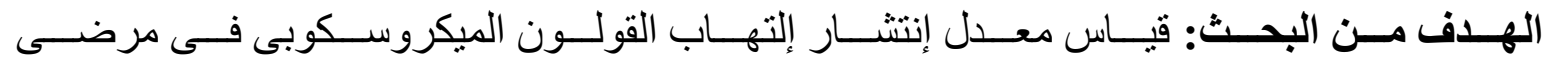
متلازمة القولون العصبى المُسهل الخاضعين لمعايير روما (4).

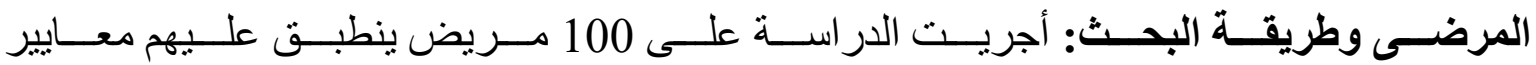

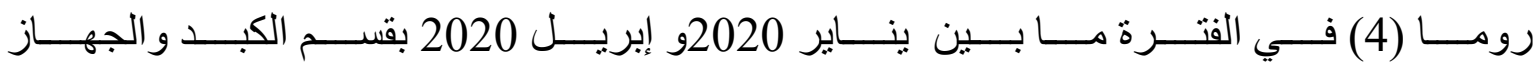

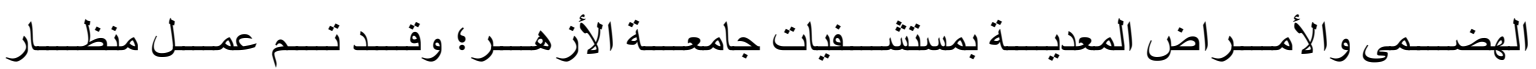
قولونى للمرضى مع أخذ عينات للفحص المجهرى.

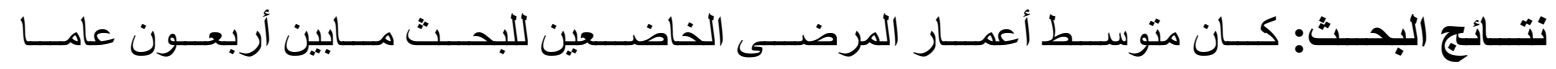

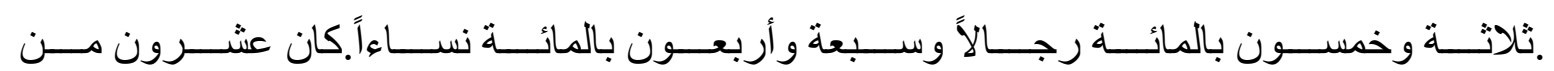

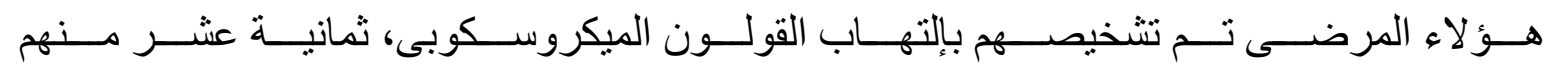

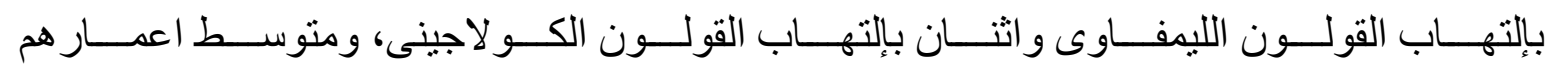

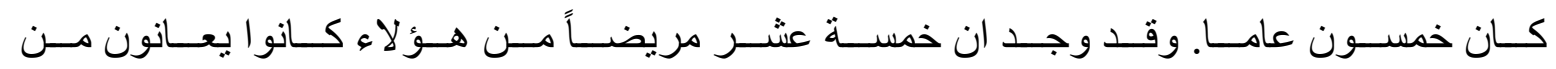




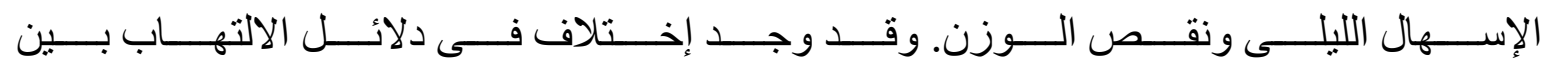
المجمو عتين ولكنها فى المعدل الطبيعى.

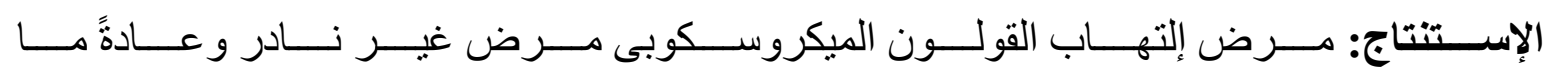

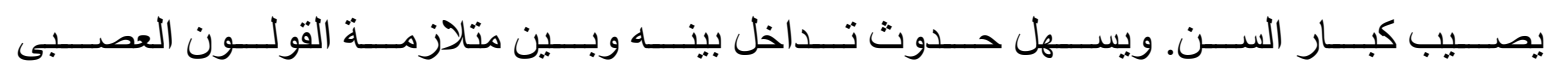

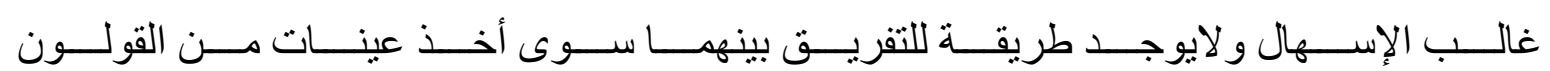

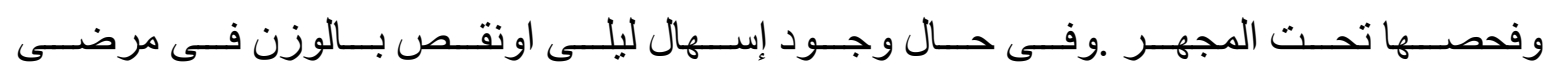

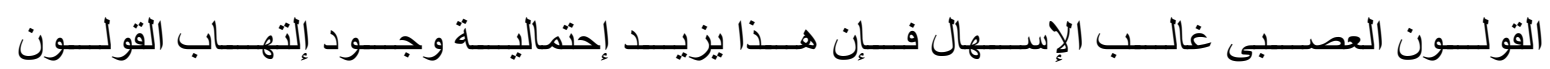

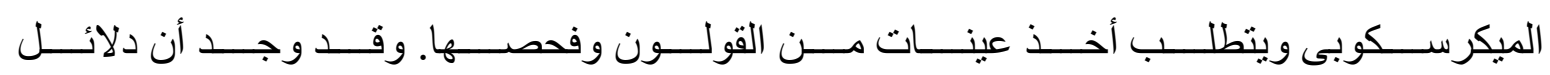

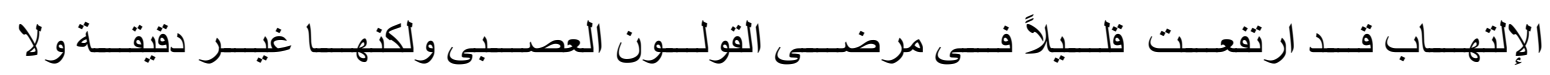
توجه نحو تثخيص إلتهاب القولون الميكروسكوبى.

الكلمات الدالة: إلتهاب القولون الميكروسكوبى - متلازمة القولون العصبى 